\title{
In vitro fermentation of corn silage using rumen fluid buffered or not and different sample amounts
}

\author{
Fermentação in vitro da silagem de milho utilizando líquido \\ ruminal tamponado ou não e três quantidades de amostras
}

\author{
Antonio Carlos Homem Junior ${ }^{\mathrm{I}}$ Jane Maria Bertocco Ezequiel ${ }^{\mathrm{II}}$ Henrique Leal Perez $^{\mathrm{III}}$ \\ Marco Tulio Costa Almeida ${ }^{\text {III }}$ Josimari Regina Paschoaloto ${ }^{\text {III }}$ Vanessa Barbosa de Carvalho ${ }^{\text {III }}$ \\ Leonardo Fernandes CremascoII Macella Borsonello da Costa ${ }^{\text {II }}$
}

\begin{abstract}
- NOTE -
ABSTRACT

Methodological variations in the amount of sample incubated and the type of rumen fluid used are commonly observed. This study evaluated the effect of three sample amounts (0.6, 1.3 or $2.6 \mathrm{~g} D M 100 \mathrm{~mL}^{-1}$ of rumen fluid) incubated in rumen fluid buffered (BRF-buffered rumen fluid) or not (PRF-pure rumen fluid) on total gas volume (TV), methane ( $\left.\mathrm{CH}_{4}\right)$ production, dry matter degradation (DM Deg) and final pH of corn silage incubated in vitro. The highest DM Deg was reached with the lowest amounts of sample (0.6 and $1.3 \mathrm{~g}$ of DM $100 \mathrm{~mL}^{-1}$ of rumen fluid). The sample amount of $2.6 \mathrm{~g}$ associated with $\mathrm{PRF}$ reduced $\mathrm{CH}_{4}$ production $(P<0.05)$, compared with the amounts of 0.6 and $1.3 \mathrm{~g} D M$ $100 \mathrm{~mL}^{-1}$, which had similar $\mathrm{CH}_{4}$ production $(P>0.05)$. The use of $B R F$ caused no effect on $\mathrm{CH}_{4}$ production $(P>0.05)$, independent of

de milho. A maior DegMS da silagem de milho foi obtida com as menores quantidades de amostra incubada (0,6 e 1,3g MS $\left.100 \mathrm{~mL}^{-1}\right)$. Para o LRP, a quantidade de 2,6g MS $100 \mathrm{~mL}^{-1}$ reduziu $(P<0,05)$ a produção de metano em comparação às quantidades de 0,6 e 1,3g $M S 100 \mathrm{~mL}^{-1}$, as quais não diferiram entre si $(P>0,05)$. Utilizando o LRT, a quantidade de amostra não modificou $(P>0,05)$ a produção de metano. Com o aumento da quantidade de amostra, houve redução do pH final da incubação em ambos os líquidos utilizados $(P<0,05)$. Os resultados do presente experimento sugerem proceder a incubação com a menor quantidade de amostra, por proporcionar pH e DegMS mais elevados. A utilização de líquido ruminal tamponado reduz a produção de metano da silagem de milho. Novas pesquisas devem ser conduzidas para verificar a possibilidade de incubação ruminal in vitro com líquido ruminal puro utilizando outros ingredientes.
\end{abstract} the sample amount. Increasing the amount of substrate resulted in lower final $\mathrm{pH}$ of incubation in both fluids $(\mathrm{P}<0.05)$. Our results indicate that incubations should be performed with the smallest amount of sample (0.6g of DM $100 \mathrm{~mL}^{-1}$ of rumen fluid), using fluid without buffer. Incubation without buffer solution overestimates the $\mathrm{CH}_{4}$ production of corn silage. Further studies should be conducted to verify the possibility of in vitro ruminal incubation of other ingredients using pure rumen fluid.

Key words: degradation, gas, incubation, methane, $p H$.

RESUMO

Variações metodológicas sobre a quantidade de amostra incubada e o tipo de líquido ruminal utilizado são comumente observadas nas pesquisas. O objetivo deste estudo foi avaliar os efeitos de três quantidades de amostra incubada (0,6; 1,3 ou 2,6g MS $100 \mathrm{~mL}^{-1}$ ) e dois tipos de líquidos ruminais (LRTlíquido ruminal tamponado ou LRP-líquido ruminal puro) sobre a produção total dos gases (VT) e de metano, a degradação da matéria seca (DegMS) e o pH final da incubação in vitro da silagem
Palavras-chave: degradação, gases, incubação, metano, $p H$.

The in vitro gas production technique is used to estimate methane $\left(\mathrm{CH}_{4}\right)$ production, rate and degree of digestibility of feed given to ruminants. In this technique, it is indicated to use rumen fluid diluted with buffer solutions, and the values obtained for $\mathrm{CH}_{4}$ production have good correlation with respirometric methods (BLUMEL et al., 1997; RYMER et al., 1999, 2005; BHATTA et al., 2006, 2008; STORM et al., 2012).

According to the review on gas production technique conducted by FONDEVILLA \& BARROS (2001), several dilutions of rumen fluid $(10,25$, or $33 \%$ rumen fluid) and sample amount $(0.66,0.83,1.0$, and $1.25 \mathrm{~g}$ of DM $100 \mathrm{~mL}^{-1}$ rumen fluid) have been used,

\footnotetext{
'Centro Estadual de Educação Tecnológica Paula Souza, Faculdade de Tecnologia (FATEC), R. Francisco Henrique Lemos, 51, 15900-000, Taquaritinga, SP, Brasil. E-mail: achomemj@hotmail.com. Corresponding author.

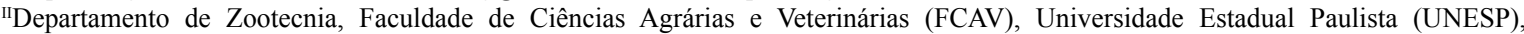
Jaboticabal, SP, Brasil.

IIIPrograma de Pós-graduação em Zootecnia, FCAV, UNESP, Jaboticabal, SP, Brasil. 
but there is no study using pure rumen fluid (PRF). MOULD et al. (2005) stated that the use of buffer solution had little influence on gas production and only minimized $\mathrm{pH}$ variations. However, RYMER et al. (2005) found that the increase in the ruminal fluid/ buffer solution ratio reduced the time of colonization and $\mathrm{pH}$ of the medium, and increased gas production. In this study, it was evaluated the effect of using ruminal fluid buffered or not and three sample amounts in the in vitro fermentation of corn silage on final $\mathrm{pH}$, total gas volume, $\mathrm{CH}_{4}$ production and DM degradation.

The study evaluated the effect of three sample amounts $\left(0.6,1.3\right.$ and $2.6 \mathrm{~g}$ of DM $100 \mathrm{~mL}^{-1}$ of rumen fluid) incubated in rumen fluid buffered (BRF-buffered rumen fluid) or not (PRF-pure rumen fluid) on total gas volume (TV), $\mathrm{CH}_{4}$ production, dry matter degradation (DM Deg) and final $\mathrm{pH}$ after 24 hours in vitro incubation at $39^{\circ} \mathrm{C}$. The incubated sample consisted of corn silage dried at $55^{\circ} \mathrm{C}$ for $72 \mathrm{~h}$ and ground to $1 \mathrm{~mm}$. Rumen fluid was collected before feeding from three cattle cannulated in the rumen and adapted to corn silage. A portion of fluid was used without adding buffer solution, and another portion of fluid was buffered at a ratio of $1: 2$ (rumen fluid: buffer $\mathrm{ANKON}^{\circledR}$ ).

Incubation was performed in $250-\mathrm{mL}$ Erlenmeyer flasks closed with silicone stoppers, and gases produced were transported by capillarity to the storage bottle. There in, it was measured the gas column height to estimate TV. After determining the $\mathrm{TV}$, an aliquot of $0.5 \mathrm{~mL}$ gas was collected with a syringe and injected into a gas chromatograph to determine $\mathrm{CH}_{4}$ concentration.

Final $\mathrm{pH}$ was measured after 24 hours incubation using a digital potentiometer. DM Deg was calculated after centrifugation for 3 minutes at 3000rpm, separation and drying the residue in an oven, subtracting the blank value (CHAUDHRY \& KHAN, 2012). Data were analyzed as a randomized complete block design in a $3 \times 2$ factorial arrangement ( 3 sample amounts $\times 2$ types of ruminal fluid) with 3 replications and 3 blank for each type of fluid. Data were subjected to analysis of variance and means were compared by Tukey's test. Statistical significance was set at $\mathrm{P} \leq 0.05$.

There was no interaction effect between sample amount $x$ type of ruminal fluid $(\mathrm{P}>0.05)$. Regardless of fluid, the greatest amount of sample incubated $\left(2.6 \mathrm{~g} \mathrm{DM} 100 \mathrm{~mL}^{-1}\right)$ resulted in lower TV and DM Deg $(\mathrm{P}<0.05)$, while the amounts of 0.6 and $1.3 \mathrm{~g} \mathrm{DM} 100 \mathrm{~mL}^{-1}$ were not significantly different from each other $(\mathrm{P}>0.05$; Figure 1$)$.

Methane production per $\mathrm{g}$ of incubated DM (mL g $\mathrm{g}^{-1}$ of DMI) was higher using the PRF $(\mathrm{P}<0.05$; Table 1). Sample amount had no effect on $\mathrm{CH}_{4}$ production using BRF. However, with PRF, the greatest sample amount $\left(2.6 \mathrm{~g}\right.$ of DM $100 \mathrm{~mL}^{-1}$ of rumen fluid) resulted in lower $(\mathrm{P}<0.05) \mathrm{CH}_{4}$ production $\left(\mathrm{mL} \mathrm{g}^{-1}\right.$ of DMI), but the amounts of 0.6 and 1.3 (g of DM $100 \mathrm{~mL}^{-1}$ of rumen fluid) were not significantly different from each other for $\mathrm{CH}_{4}$ production $(\mathrm{P}>0.05)$.

The greater the sample amount was, the lower the final $\mathrm{pH}$ of incubation, regardless of ruminal fluid types $(\mathrm{P}<0.05)$. $\mathrm{PRF}$ showed a higher final $\mathrm{pH}$ of incubation with sample amounts of 0.6 and $1.3 \mathrm{~g}$ of DM $100 \mathrm{~mL}^{-1}$ compared with BRF $(\mathrm{P}<0.05)$. However, for the greatest sample amount (2.6g of DM $100 \mathrm{~mL}^{-1}$ rumen fluid), there was no difference in final $\mathrm{pH}$ between the types of fluids used $(\mathrm{P}>0.05)$. The final $\mathrm{pH}$ was lower than 5.4 using $2.6 \mathrm{~g}$ of DM $100 \mathrm{~mL}^{-1}$ rumen fluid.

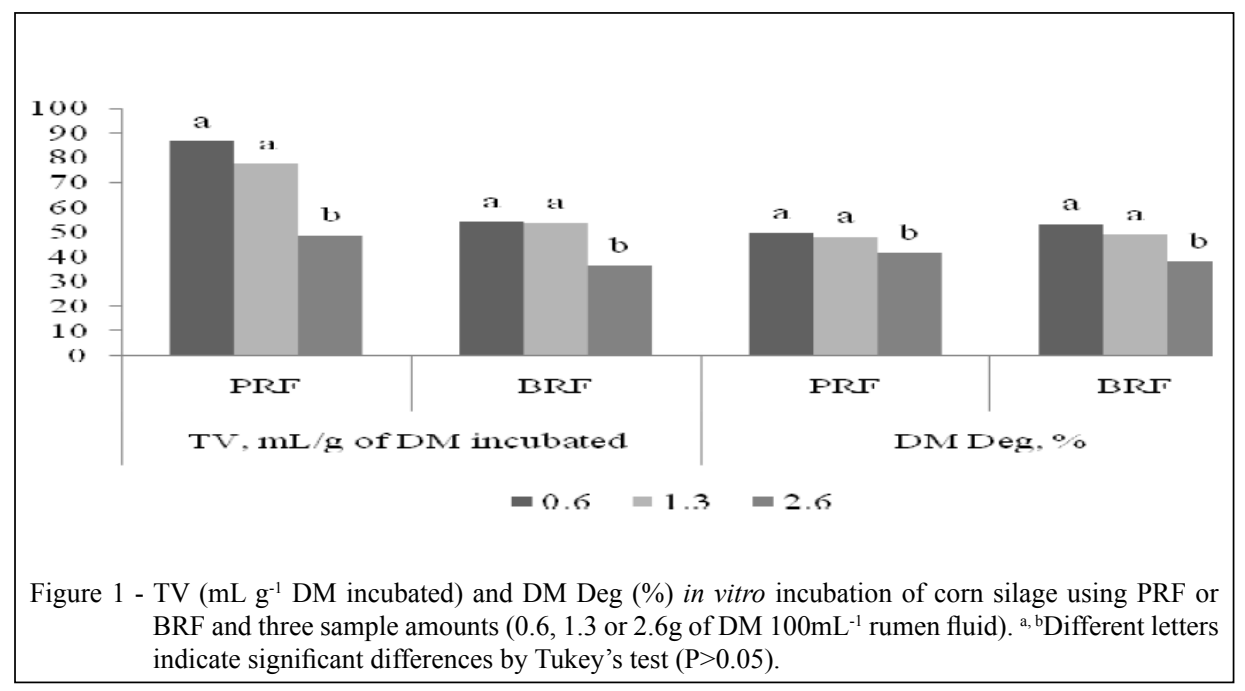

Ciência Rural, v.45, n.12, dez, 2015. 
Table 1 - Methane production and final $\mathrm{pH}$ of in vitro incubation of corn silage using PRF or BRF with three sample amounts.

\begin{tabular}{|c|c|c|c|c|c|c|c|c|}
\hline \multirow{2}{*}{ Item } & \multirow{2}{*}{$\begin{array}{l}\text { Sample } \\
\text { amount }^{2}\end{array}$} & \multicolumn{2}{|c|}{--------- Rumen fluid --------- } & \multirow{2}{*}{ Mean } & \multirow{2}{*}{ RMSE } & \multicolumn{3}{|c|}{------------------------ Effect ---------------------. } \\
\hline & & PRF & $\mathrm{BRF}$ & & & Amount & Fluid & Interaction \\
\hline \multirow{4}{*}{$\mathrm{CH}_{4}{ }^{1}$} & 0.6 & $22.38 \mathrm{Aa}$ & $10.00 \mathrm{Ab}$ & $16.19 \mathrm{~A}$ & \multirow{4}{*}{1.27} & \multirow{4}{*}{$* * *$} & \multirow{4}{*}{$* * *$} & \multirow{4}{*}{$* * *$} \\
\hline & 1.3 & $19.44 \mathrm{Aa}$ & $12.11 \mathrm{Ab}$ & $15.77 \mathrm{~A}$ & & & & \\
\hline & 2.6 & $13.53 \mathrm{Ba}$ & $8.82 \mathrm{Ab}$ & $11.17 \mathrm{~B}$ & & & & \\
\hline & Mean & $18.45 \mathrm{a}$ & $10.31 \mathrm{~b}$ & & & & & \\
\hline \multirow{4}{*}{ Final $\mathrm{pH}$} & 0.6 & $6.65 \mathrm{Aa}$ & $6.49 \mathrm{Ab}$ & $6.57 \mathrm{~A}$ & \multirow{4}{*}{0.03} & \multirow{4}{*}{$* * *$} & \multirow{4}{*}{$* * *$} & \multirow{4}{*}{$* * *$} \\
\hline & 1.3 & $6.13 \mathrm{Ba}$ & $5.85 \mathrm{Bb}$ & $5.99 \mathrm{~B}$ & & & & \\
\hline & 2.6 & $5.38 \mathrm{Ca}$ & $5.32 \mathrm{Ca}$ & $5.35 \mathrm{C}$ & & & & \\
\hline & Mean & $6.05 \mathrm{a}$ & $5.89 \mathrm{~b}$ & & & & & \\
\hline
\end{tabular}

Mean values in the same row followed by different lowercase letters and mean values in the same column followed by different uppercase letters are significantly different by Tukey's test $(\mathrm{P}>0.05) ;{ }^{1} \mathrm{~mL} \mathrm{~g}^{-1} \mathrm{DM}$ incubated; ${ }^{2}$ Sample amount $\mathrm{g} 100 \mathrm{~mL}^{-1}$ rumen fluid; PRF- Pure rumen fluid, BRF- Buffered rumen fluid; RMSE- Root mean square error; $* * * \mathrm{P}<0.0001$.

In the present study, the reduction in $\mathrm{pH}$ with greater amount of sample was probably due to the saturation of fluid, which had higher concentration of volatile fatty acids produced by fermentation, which can inhibit the activity of rumen microorganisms. Consequently, it may reduce DM Deg and $\mathrm{CH}_{4}$ production per $\mathrm{g}$ of DM incubated (RAMIN \& HUHTANEN, 2012). Higher $\mathrm{CH}_{4}$ production using PRF, regardless of the sample amount, indicated no negative effect in the absence of buffer in the ruminal fluid. Thus, it is possible to conduct in vitro incubation of corn silage without buffer solution.

The final $\mathrm{pH}$ at 5.8 indicated the excess of sample, which is possibly the decisive factor in reducing DM Deg (Figure 1), since the microbiota fermenting fiber carbohydrates is inhibited by $\mathrm{pH}$ reduction. RYMER et al. (2005) incubated hay or wheat grain using different ratios of rumen fluid/buffer solution and reported reduction in final $\mathrm{pH}$ of in vitro incubation related to the decreased amount of buffer solution, differently from the findings of this study.

The lowest amount of sample incubated $\left(0.6 \mathrm{~g}\right.$ of $\mathrm{DM} 100 \mathrm{~mL}^{-1}$ rumen fluid) associated with PRF improved the DM Deg, resulting in higher $\mathrm{TV}$, which may be related to lower production rate of fermentation end products. Unlike, in in vivo conditions, end products leave the rumen by absorption or passage, but in in vitro system, they remain in the rumen, indicating that the use of buffer is important when greater amounts of corn silage are incubated.

The results suggested the possibility of incubation with the lowest sample amount, because it provides higher final $\mathrm{pH}$ and higher DM Deg. The use of buffered rumen fluid reduces $\mathrm{CH}_{4}$ production from corn silage. Further studies should be carried out to verify the possibility of in vitro ruminal incubation with pure rumen fluid using other feedstuffs.

\section{BIOETHICS AND BIOSSECURITY COMMITTEE APPROVAL}

Authors declaration

We, authors of the article entitled In vitro fermentation of corn silage using buffered rumen fluid or not and three amounts of sample, declare that the data from this study were not submitted for evaluation to the Ethics and Biosafety Committee of the Faculdade de Ciências Agrárias e Veterinárias (FCAV), Universidade Estadual Paulista (UNESP) in Jaboticabal, São Paulo State, but we are aware of the rules, and therefore, the experiment was conducted in accordance with the laws and regulations which controlls experiments that use live animals in Brazil - Conselho Nacional de Controle de Experimentação Animal (CONCEA) $<$ http://www.mct.gov>, $\quad<$ http://www.mct.gov.br/index.php/ content/view/310553.html $>$. Thus, the authors assume full responsibility for the data and are available for possible questions.

\section{REFERENCES}

BHATTA, R. et al. Comparison of sulfur hexafluoride tracer technique, rumen simulation technique and in vitro gas production techniques for methane production from ruminant feeds. International Congress Series, v.1293, p.58-61, 2006. Available from: $<\mathrm{http}: / / \mathrm{www}$. sciencedirect.com/science/article/pii/ S0531513106003633>. Accessed: Dec. 15, 2013. doi: 10.1016/j. ics.2006.03.075.

BHATTA, R. et al. Diet effects on methane production by goats and a comparison between measurement methodologies. Journal of Agricultural Science, v.146, p.705-715, 2008. Available from: $<$ http://journals.cambridge.org/action/displayAbstract?fromPage $=$ online \&aid $=2706356 \&$ fileId $=$ S0021859608007983 $>$. Accessed: Dec. 13, 2013. doi: 10.1017/S0021859608007983.

BLUMMEL, M. et al. In vitro gas production: a technique revisited. Journal of Animal Physiology and Animal Nutrition, v.77, 
p.24-34, 1997. Available from: <http://onlinelibrary.wiley.com/ doi/10.1111/j.1439-0396.1997.tb00734.x/abstract>. Accessed: Dec. 13, 2013. doi: 10.1111/j.1439-0396.1997.tb00734.x.

CHAUDHRY, A.S.; KHAN, M.M.H. Impacts of different spices on in vitro rumen dry matter disappearance, fermentation and methane of wheat or ryegrass hay based substrates. Livestock Science, v.146, p.84-90, 2012. Available from: <http://www.sciencedirect. com/science/article/pii/S1871141312000339>. Accessed: Dec. 15, 2013. doi: 10.1016/j.livsci.2012.01.007.

FONDEVILA, M; BARRIOS, A. The gas production technique and its application to the study of the nutritive value of forages. Cuban Journal of Agricultural Science, v.35, p.187-196, 2001.

MOULD, F.L. et al. In vitro microbial inoculum: a review of its function and properties. Animal Feed Science and Technology, v.123-124, p.31-50, 2005. Available from: <http://centaur. reading.ac.uk/8947>. Accessed: Dec. 15, 2013. doi: 10.1016/j. anifeedsci.2005.04.028.

RAMIN, M.; HUHTANEN, P. Development of an in vitro method for determination of methane production kinetics using a fully automated in vitro gas system-A modelling approach.
Animal Feed Science and Technology, v.174, p.190-200, 2012. Available from: $<$ http://www.sciencedirect.com/science/article/pii/ S0377840112001174>. Accessed: Dec. 13, 2013. doi: 10.1016/j. anifeedsci.2012.03.008.

RYMER, C. et al. Effects of inoculum preparation method and concentration, method of inoculation and pre-soaking the substrate on the gas production profile of high temperature dried grass. Animal Feed Science and Technology, v.78, p.199-213, 1999. Available from: $<$ http://www.sciencedirect.com/science/article/pii/ S0377840199000061>. Accessed: Nov. 16, 2013. doi: 10.1016/ S0377-8401(99)00006-1.

RYMER, C. et al. In vitro cumulative gas production techniques: history, methodological considerations and challenges. Animal Feed Science and Technology, v.123-124, p.9-30, 2005. Available from: $<$ http://www.sciencedirect.com/science/article/pii/ S0377840105001719>. Accessed: Nov. 16, 2013. doi: 10.1016/j. anifeedsci.2005.04.055.

STORM, I.M.L.D. et al. Methods for measuring and estimating methane emission from Ruminants. Animals, v.2, p.160-183, 2012. Available from: <http://www.mdpi.com/2076-2615/2/2/160>. Accessed: Nov. 16, 2013. doi: 10.3390/ani2020160. 